\title{
Work Pressures Among Teachers of Learning Disabilities in English Language from
} their Point of View

\author{
Mohammad Ahmad Saleem Khasawneh ${ }^{1}$ 잉 \\ Corresponding Email: mkhasawneh@kku.edu.sa \\ ${ }^{1}$ Assistant Professor, Special Education Department, King Khalid University, Saudi Arabia \\ Received: August 5, 2021 \\ Revised: August 26, 2021 \\ Accepted: September 9, 2021
}

\begin{abstract}
This study aimed at identifying the work pressures among teachers of learning disabilities in English language in Irbid governorate from their point of view. The total number of the study population was (60) male and female teachers, while the study sample included (30) male and female teachers. To collect the study information, the researcher developed a questionnaire to reveal the level of work stress among male and female teachers, and it included (40) items. The study found that there are pressures at work for teachers of LDs in English language. These pressures are the poor achievement of some students, large financial obligations for teachers, poor standards used to promote teachers, the large number of lessons taught by the teacher per week, daily planning, and overcrowding of students in class. The study recommended holding training courses for teachers in the private sector, similar to their colleagues in other sectors, to improve the educational process, and so that teachers can keep pace with the rapid scientific and technological development that the world is witnessing around them.
\end{abstract}

Keywords: Work Pressure, Learning Disabilities in English Language, Teachers

\section{Introduction}

Work pressure has captured the attention of many countries of the developed world, and this concern is due to the fear of these countries of the effects of pressure on the behavior of individuals and groups, their job performance, and the institutions in which they work. Pressure at work increases burdens to the national economy of these countries. Therefore, sound management must give pressure at work the attention it deserves so that its employees can perform their jobs efficiently and effectively (Al-Otaibi, 2003).

Any individual does not live without pressure. The moderate amount of pressure is useful and may have positive results, motivation, and incentives that help improve job performance. However, excess pressure is what must be avoided because it makes the individual loses his abilities and energies in adapting and overcoming stress. Any physical exhaustion or an unpleasant psychological state such as anxiety, frustration, and pain is directly related to the work pressures that man is exposed to (Singh, \& Srivastava, 2018). Work stress causes a person many mental and physical diseases and disorders, such as heart disease, high blood pressure, high cholesterol, anxiety, frustration, and headaches (Na-Nan et al, 2018).

Given the importance of the role that the teacher plays in the educational process, researchers in the field of education have been interested in identifying the sources of work pressures that the teacher is exposed to reduce the impact of these pressures on teachers, whose effects are undoubtedly reflected on their job performance (Mohammed, 2015).

Through the studies that were conducted on work stress, the level of pressure on teachers has risen significantly during the modern era. The results of these studies have indicated that teachers are under pressure more than other professions because of the many conflicting and 
expected demands from them, the ambiguity of the role, and the continuous exposure to stressful situations (Al-Sameeh, 2020).

By looking at the previous factors, it is noted that any process of change in any of them may lead to a change in the level of job performance for individuals. An employee who has the motivation to achieve and possesses the necessary knowledge and skill will inevitably be better able to face work pressures than an employee who does not possess them, which reflects positively on his job performance. The employee who feels that his job offers him opportunities for promotion and self-realization, and the necessary resources and tools are available to him and works in a healthy environment that is better able to face difficulties at work.

The teaching profession is one of the social professions that requires its workers to have many tasks and high skills. The teacher deals with values, trends, and demands to inculcate them in immature children. The teacher's job includes preparing for lessons and giving lectures, setting annual plans, participating in various courses and committees, and carrying out extra-curricular activities. shifts, following up on students' attendance and absence, correcting papers, monitoring grades, raising classes, making schedules, in addition to the workload officially assigned to him. Therefore, the researcher tried in this study to reveal the work pressures that teachers of LDs in English language are exposed to. However, despite the importance of this topic and its danger to teachers' health and job performance, it has not received sufficient attention in Arabic literature and studies except for a few studies. Interest in the issue of work stress is still limited to some procedural and theoretical studies, and there are no statistics to the knowledge of the researcher, that explain the impact of pressure on the economy and work in the Arab world.

This study aimed at answering the following question: (1) What is the level of work stress among teachers of learning disabilities in English language from their point of view?

The significance of this study comes from the importance of the topic it deals with, as this study addresses the following dimensions. The Human Dimension. This study is concerned with the physical aspect and its impact on the job performance of teachers of LDs in English language, who have not given enough attention in local and Arabic studies and literature. The productive dimension. This study is concerned with the production of teachers of LDs in English language and their job performance to work on improving it and raising its level. The evaluative dimension. This study is expected to make those in charge of the educational process aware of the reality of what is happening in the field in terms of weakness, strength, or wrong practices in Jordanian schools to work on addressing and confronting them.

However, this study was limited to teachers of LDs in English Language for the academic year 2020/2021. The study is limited to the instrument of the study and the responses of the study sample members to the items of the instrument developed by the researcher in this study.

\section{Literature Review}

Most people in our time face different types of pressures at work. Because of stress, there are examples are many of employees' failure to adapt to the requirements and conditions of work, organization policy, leadership and supervisory style, difficult financial conditions, high cost of living, traffic congestion, noise, environmental pollution, unemployment, family problems, etc. (Hareem, 2007).

The word (Stress) derives from the Latin word (Stringere) which means closer, tighten, tight, and bind. The French word (Etreindre) is also generated from the word stress, and it means surrounds the body and organs with strong tension. We do not find the word (Stress) in the French language before the twentieth century, but on the contrary, it has been used in the English language for centuries and has been used since the seventeenth century to express pain, 
deprivation, adversity, obsessions, disasters, and strife, that is, it expresses, in general, the results of a harsh life (Stora, 2011).

The pressure resulting from the role conflict appears clearly among teachers who work in remote areas, where their work requires them to reside in their workplace and thus contradicts their role as parents and husbands. The pressure from the ambiguity of the role of the teacher appears among new teachers, where their knowledge of their rights and duties is limited.

There are also many burdens on the teacher during the exercise of his role, such as giving lectures, preparing lessons, raising classes and shifts, preparing plans and extracurricular activities, monitoring grades, making schedules, following up on the attendance and absence of students, and attending courses. All of this constitutes heavy burdens on the teacher and affects performance (Abolqasem, 2020).

Many studies have indicated the sources or causes of pressure in teachers. Fuller explained that the lack of student discipline in the classroom, the teacher's inability to answer their questions, and the problems of evaluating students' performance are among the important sources that cause pressure for the teacher. Pratt identified five main sources of pressure the teacher is exposed to, which are the inability of the teacher to overcome the teaching problems, the lack of cooperation of students in the classroom, aggressive students, the curricula and teaching methods used, and the relationship between teachers (Al-Mutairi, 2020).

\section{Previous Studies}

Lutfi (2019) identified the level of both work stress and organizational commitment among teachers of the second cycle of basic education schools in Menoufia Governorate from their point of view. The study used the descriptive-analytical approach. The research sample included (274) male and female teachers from Menoufia Governorate. The results showed the presence of work pressures to a medium degree among teachers of the second cycle of basic education in Menoufia Governorate. The organizational commitment was to a large extent among teachers. The results showed the existence of a negative correlation between role conflict and organizational commitment, and the absence of a correlation between role burden and organizational commitment.

Al-Muaqil (2016) explored the relationship between emotional intelligence and strategies for coping with work pressures among teachers of intellectual disabilities. The research sample included (53) teachers in the institutes of intellectual education, east of Riyadh. The Bar-On Emotional Intelligence Scale and the Work Stress Management Strategies Scale were applied. The results revealed a significant relationship between emotional intelligence and strategies for coping with work stress among teachers, and there are statistically significant differences in teachers' coping strategies that are attributed to gender, in favor of female teachers. the results showed no statistically significant differences in strategies for coping with stress among teachers attributed to the number of years of experience. It is possible to predict from the emotional intelligence of teachers with intellectual disabilities their strategies in facing work pressures.

Al-Fraihat (2016) investigated the sources of work stress for teachers of the lower basic stage in Ajloun Governorate. The study sample consisted of (100) male and female teachers who work in public schools in the lower basic education stage in Ajloun Governorate, for the academic year 2009/2010. The work stress scale prepared by the researchers was used for this study. The results of the study indicated that the rate of work stress was high among teachers. The arrangement of work sources as seen by the teachers of the basic stage in Ajloun Governorate was as follows: occupational satisfaction, school environment, teaching load, relationship with management, relationship with colleagues, relationship with students. The 
results of the study indicated that there were no statistically significant differences in the extent of teachers' exposure to work pressures due to any of the variables.

Al-Judou (2015) investigated the sources of work stress among special education teachers in Amman Governorate. The study sample consisted of (170) male and female teachers who were selected by stratified random method from public and private schools and centers for the 20122013 academic year. To achieve the goal of the study, the researcher built the study tool represented by the questionnaire, which consisted of 70 paragraphs distributed over seven fields. The results of the study indicated that the total degree of sources of work stress for special education teachers in Amman governorate was high. The results also indicated that there were statistically significant differences in the sources of work stress among special education teachers according to the variables gender in favor of females.

McManus et al (2004) explored the extent to which approaches to work, workplace climate, stress, burnout, and satisfaction with medicine as a career in doctors aged about thirty are predicted by measures of learning style and personality measured five to twelve years earlier when the doctors were applicants to medical school or were medical students. Doctors' approaches to work were predicted by study habits and learning styles, both at application to medical school and in the final year. How doctors perceive their workplace climate and workload is predicted both by approaches to work and by measures of stress, burnout, and satisfaction with medicine.

Kwakman (2001) explored the Job Demand-Control model was used to study the quality of working life of Dutch secondary teachers. The Job Demand-Control model of Karasek is a theoretical model in which stress and learning are both considered as dependent variables which are influenced by three different task characteristics: job demands, job control, and social support. This model was tested for Dutch secondary teachers $(n=542)$. Results shed light on the relationship between stress and learning, on the one hand, and the effects of task characteristics on work stress and work-based learning, on the other hand. It is concluded that the relationship between stress and learning is mediated by the amount of job control as the model predicts

\section{Methods}

This study used the descriptive method and developed a questionnaire to collect data for analysis. The study population consisted of (60) male and female teachers, and the study sample included (30) male and female teachers.

\section{Instrument of the Study}

The instrument of the study was developed after defining the concept of the study variable, which is work stress. The dimensions of the study were determined, which are students, parents and society, family pressures, management and supervision, teaching and working conditions, and curricula. The necessary information for the study was obtained by referring to previous research and studies and theoretical literature related to the subject of the study.

To ensure the validity of the instrument, the researcher presented the study instrument to specialized professors. After the instrument was collected from specialists and judges, the researcher studied the opinions, suggestions, observations, and modifications that were received regarding the paragraphs from deleting and adding some words and phrases and the linguistic formulation of some paragraphs of the instrument.

The researcher used two methods to verify the reliability of the instrument. First, the Test-reTest method. To ensure the reliability of the instrument, the researcher distributed it to a sample of (15) male and female teachers from outside the study population, and after two weeks, the 
same instrument was redistributed to the same sample of the study. The Pearson coefficient was 0.96, and this indicates a high stability coefficient.

Second, the researcher used Cronbach's alpha equation to verify the value of the internal consistency of the study instrument and to know the strength of the correlation between the paragraphs of the tool. The researcher obtained acceptable results for this study and expresses the ability of the instrument to achieve its goal

\section{Results and Discussion}

Results related to the study question: What is the level of work stress among teachers of LDs in English language from their point of view?

To answer this question, the mean scores and standard deviations were used for each field of study, and Table (1) illustrates the results.

Table 1. The mean scores and standard deviations of teachers' work stress dimensions, arranged in descending order

\begin{tabular}{|c|l|c|c|c|}
\hline NO. & \multicolumn{1}{|c|}{ Dimension } & $\begin{array}{c}\text { Mean } \\
\text { scores }\end{array}$ & $\begin{array}{c}\text { Standard } \\
\text { deviation }\end{array}$ & rank \\
\hline 5 & Parents and the community & 3.19 & .62 & 1 \\
\hline 6 & Curriculum & 3.17 & .67 & 2 \\
\hline 4 & family pressures & 3.08 & .68 & 3 \\
\hline 2 & Teaching and working conditions & 3.07 & .59 & 4 \\
\hline 1 & Students & 2.98 & .63 & 5 \\
\hline 3 & Management and supervision & 2.87 & .65 & 6 \\
\hline & Total & 3.07 & .50 & \\
\hline
\end{tabular}

Table (1) shows that the mean scores of work stress for teachers of learning disabilities ranged between (3.19-2.87). The dimension of parents and community got the highest mean score (3.19), while the field of management and supervision got the lowest mean score (2.87). The total mean score of the six dimensions was (3.07).

The following is a presentation of the mean scores and standard deviations of the paragraphs of each dimension of the study, arranged in descending order according to the mean scores.

Table 2. The mean scores and standard deviations of teachers' responses to the students' dimension

\begin{tabular}{|c|l|c|c|}
\hline NO. & \multicolumn{1}{|c|}{ Paragraph } & $\begin{array}{c}\text { Mean } \\
\text { score }\end{array}$ & $\begin{array}{c}\text { Standard } \\
\text { deviation }\end{array}$ \\
\hline 1 & Student abuse of the teacher. & 3.28 & 1.19 \\
\hline 2 & Socioeconomic differences among students. & 3.16 & 1.17 \\
\hline 3 & Students' quarrels inside the school. & 2.92 & 1.14 \\
\hline 4 & Students' absence. & 2.88 & 1.11 \\
\hline 5 & $\begin{array}{l}\text { Students do not bring stationery and } \\
\text { textbooks. }\end{array}$ & 2.86 & 1.15 \\
\hline 6 & Poor methods of evaluating students. & 2.84 & 1.09 \\
\hline 7 & $\begin{array}{l}\text { Lack of cleanliness and safety of students' } \\
\text { books and notebooks. }\end{array}$ & 2.81 & 1.16 \\
\hline 8 & $\begin{array}{l}\text { Students' unwillingness to participate in } \\
\text { cultural and sports competitions. }\end{array}$ & 2.78 & 1.04 \\
\hline 9 & Having troubled students in the class. & 2.72 & 1.41 \\
\hline 10 & Students do not accept the teacher. & 2.53 & 1.31 \\
\hline
\end{tabular}


Table 3. The mean scores and standard deviations of teachers' responses to the parents and the community dimension

\begin{tabular}{|c|l|c|c|}
\hline NO. & \multicolumn{1}{|c|}{ Paragraph } & $\begin{array}{c}\text { Mean } \\
\text { score }\end{array}$ & $\begin{array}{c}\text { Standard } \\
\text { deviation }\end{array}$ \\
\hline 11 & Society's negative view of the teacher. & 3.42 & 1.07 \\
\hline 12 & Negative parental interference in school work. & 3.36 & 1.29 \\
\hline 13 & $\begin{array}{l}\text { Parents' lack of interest in the cleanliness and } \\
\text { arrangement of their children. }\end{array}$ & 3.25 & 1.18 \\
\hline 14 & $\begin{array}{l}\text { Poor cooperation between parents and } \\
\text { teachers. }\end{array}$ & 3.12 & 1.19 \\
\hline 15 & $\begin{array}{l}\text { The teacher is required to attend the Parent- } \\
\text { Teacher Council. }\end{array}$ & 3.12 & 1.25 \\
\hline 16 & The poor educational level of parents. & 2.98 & 1.14 \\
\hline 17 & $\begin{array}{l}\text { Parents not attending parent-teacher } \\
\text { conferences. }\end{array}$ & 2.88 & 1.05 \\
\hline 18 & The many demands of parents from teachers. & 2.42 & .98 \\
\hline
\end{tabular}

Table 4. The mean scores and standard deviations of teachers' responses to the family pressure dimension

\begin{tabular}{|c|l|c|c|}
\hline NO. & \multicolumn{1}{|c|}{ Paragraph } & $\begin{array}{c}\text { Mean } \\
\text { score }\end{array}$ & $\begin{array}{c}\text { Standard } \\
\text { deviation }\end{array}$ \\
\hline 19 & $\begin{array}{l}\text { Lack of support and encouragement on the } \\
\text { part of the family. }\end{array}$ & 2.96 & 1.23 \\
\hline 20 & Lots of family events. & 2.87 & 1.18 \\
\hline 21 & Poor relationship with family members. & 2.83 & .99 \\
\hline 22 & Family problems with community members. & 2.77 & 1.02 \\
\hline 23 & A large number of family members. & 2.75 & 1.21 \\
\hline 24 & $\begin{array}{l}\text { Family members' interference in the teacher's } \\
\text { work. }\end{array}$ & 2.74 & 1.38 \\
\hline 25 & $\begin{array}{l}\text { Being late for home because of the distance to } \\
\text { work. }\end{array}$ & 2.73 & 1.15 \\
\hline 26 & $\begin{array}{l}\text { The inconvenience and lack of a comfortable } \\
\text { atmosphere by the family. }\end{array}$ & 2.56 & 1.19 \\
\hline 27 & $\begin{array}{l}\text { Negative observations of the family on the } \\
\text { teaching profession. }\end{array}$ & 2.26 & 1.02 \\
\hline 28 & Studying at the University. & 2.09 & 1.01 \\
\hline
\end{tabular}

Table 5. The mean scores and standard deviations of teachers' responses to the management and supervision dimension

\begin{tabular}{|c|l|c|c|}
\hline NO. & \multicolumn{1}{|c|}{ Paragraph } & $\begin{array}{c}\text { Mean } \\
\text { score }\end{array}$ & $\begin{array}{c}\text { Standard } \\
\text { deviation }\end{array}$ \\
\hline 29 & $\begin{array}{l}\text { Management's lack of appreciation for the } \\
\text { teacher's efforts and achievements. }\end{array}$ & 3.18 & 1.16 \\
\hline 30 & Poor standards in evaluating teachers. & 3.17 & 1.22 \\
\hline 31 & $\begin{array}{l}\text { Weak supervisory assistance from the } \\
\text { educational supervisor. }\end{array}$ & 3.14 & 1.23 \\
\hline 32 & $\begin{array}{l}\text { Unfair distribution of study materials to } \\
\text { teachers. }\end{array}$ & 3.13 & 1.22 \\
\hline 33 & Weak disciplinary policy in the school. & 3.02 & 1.11 \\
\hline
\end{tabular}




\begin{tabular}{|c|l|c|c|}
\hline 34 & $\begin{array}{l}\text { The administration's failure to take into account } \\
\text { the teachers' conditions when distributing } \\
\text { assignments to them. }\end{array}$ & 3.01 & 1.14 \\
\hline 35 & $\begin{array}{l}\text { The school administration's lack of attention to } \\
\text { the students' achievement weakness. }\end{array}$ & 3.01 & 1.19 \\
\hline 36 & $\begin{array}{l}\text { Lack of teachers' encouragement for innovation } \\
\text { The principal's lack of commitment to the } \\
\text { principle of a good example in word and deed. }\end{array}$ & 2.99 & 1.09 \\
\hline 38 & $\begin{array}{l}\text { Failure to provide the administration with the } \\
\text { educational needs and requirements of teachers. }\end{array}$ & 2.83 & 1.14 \\
\hline
\end{tabular}

Table 6. The mean scores and standard deviations of teachers' responses to the Teaching and working conditions dimension

\begin{tabular}{|c|c|c|c|}
\hline NO. & Paragraph & $\begin{array}{l}\text { Mean } \\
\text { score }\end{array}$ & $\begin{array}{l}\text { Standard } \\
\text { deviation }\end{array}$ \\
\hline 39 & Crowded students in the classroom. & 3.58 & 1.28 \\
\hline 40 & Low salaries. & 3.56 & 1.24 \\
\hline 41 & The teacher is required to attend training courses. & 3.54 & 1.19 \\
\hline 42 & $\begin{array}{l}\text { Lack of professional advancement in the teaching } \\
\text { profession. }\end{array}$ & 3.43 & 1.29 \\
\hline 43 & Poor school and classroom construction. & 3.19 & 1.21 \\
\hline 44 & $\begin{array}{l}\text { Requiring the teacher to follow a certain method of } \\
\text { teaching. }\end{array}$ & 3.13 & 1.15 \\
\hline 45 & Poor ventilation and lighting in the classrooms. & 3.05 & 1.33 \\
\hline 46 & Noise from inside and outside the school. & 3.03 & 1.26 \\
\hline 47 & $\begin{array}{l}\text { Conducting exams and recording results within a } \\
\text { specified time. }\end{array}$ & 2.96 & 1.23 \\
\hline 48 & $\begin{array}{l}\text { Lack of clarity of work requirements and } \\
\text { responsibilities. }\end{array}$ & 2.93 & 1.16 \\
\hline
\end{tabular}

Table 7. The mean scores and standard deviations of teachers' responses to the curricula dimension

\begin{tabular}{|c|l|c|c|}
\hline NO. & \multicolumn{1}{|c|}{ Paragraph } & $\begin{array}{c}\text { Mean } \\
\text { score }\end{array}$ & $\begin{array}{c}\text { Standard } \\
\text { deviation }\end{array}$ \\
\hline 49 & Frequent change in the curriculum. & 3.64 & 1.22 \\
\hline 50 & $\begin{array}{l}\text { The curricula do not take into account the needs and } \\
\text { tendencies of the students. }\end{array}$ & 3.58 & 1.21 \\
\hline 51 & The large information in the curriculum. & 3.45 & 1.08 \\
\hline 52 & Inadequate curriculum for the age level of the students. & 3.37 & 1.07 \\
\hline 53 & $\begin{array}{l}\text { Teachers are not involved when developing the } \\
\text { curriculum. }\end{array}$ & 3.33 & 1.08 \\
\hline 54 & $\begin{array}{l}\text { The curriculum does not take into account the } \\
\text { individual differences between students. }\end{array}$ & 3.23 & 1.11 \\
\hline 55 & The illogical sequence in the content of the curriculum. & 3.02 & 1.17 \\
\hline 56 & $\begin{array}{l}\text { The curriculum's lack of comprehensiveness for } \\
\text { aspects of human behavior. }\end{array}$ & 2.93 & 1.09 \\
\hline 57 & $\begin{array}{l}\text { Difficulty applying the activities mentioned in the } \\
\text { book. }\end{array}$ & 2.96 & 1.05 \\
\hline 58 & $\begin{array}{l}\text { The ambiguity of graphics, shapes, and images inside } \\
\text { the books. }\end{array}$ & 2.94 & 1.19 \\
\hline
\end{tabular}




\begin{tabular}{|c|l|c|c|}
\hline 59 & $\begin{array}{l}\text { The lack of appropriateness of the language of the } \\
\text { book to the level of students. }\end{array}$ & 2.72 & 1.17 \\
\hline 60 & $\begin{array}{l}\text { Poor coherence and integration of the curriculum } \\
\text { content elements. }\end{array}$ & 2.48 & 1.08 \\
\hline
\end{tabular}

It is clear from the foregoing that the dimension of teaching and working conditions cause teachers more pressure at work than other dimensions. As for the dimension of family pressure, it causes teachers less pressure at work than other dimensions of the study. This may be due to the large number of lessons taught by teachers per week, the salaries they receive, and the training courses that teachers are obliged to attend to keep pace with the rapid practical and technological development that education is going through in Jordan, as well as daily and quarterly planning. Other causes of stress included the student crowding in classes, and obligating the teacher to implement the curriculum and take exams within a specified schedule by the supervisory authority.

\section{Conclusion}

Through our review of previous studies, and the results of this study, we can make the following recommendations; (1) Holding training courses for teachers of learning disabilities to improve the educational process, and to be able to keep pace with the rapid scientific and technological development witnessed by the world around them; (2) Studying the pressures mentioned in this study by educational officials and working to confront them before they increase. These pressures must be taken into consideration when adopting or amending new educational policies. Preparing training programs and courses by specialists in the field of educational administration and training teachers on how to deal with the work pressures they face.

\section{Acknowledgments}

The authors extend their appreciation to the Deanship of Scientific Research at King Khalid University for funding this work through Big Research Groups under grant number (RGP.2 /103/42).

\section{References}

Al-Fraihat, A., Miqdadi, Y. \& Al-Fraihat, A. M. (2016). Sources of Work Pressure Among First Basic Stage Teachers in Ajloun Governorate - Jordan. Journal of the Association of Arab Universities for Education and Psychology: Damascus University - College of Education, 14(3), 311 - 334. http://search.mandumah.com/Record/773436

Al-Judou, E. A. (2015). Job Stress Sources for Teachers of Special Education in Amman and their Relationship with the Variables. Studies - Educational Sciences University of Jordan-Deanship of Scientific Research, 42(2), 361 - 393. http://search.mandumah.com/Record/670243

Al-Muaqil, I. A. (2016). Emotional intelligence and its relationship to Strategies in Facing Work Stress by Teachers of Students with Intellectual Disabilities. Journal of Educational Sciences: King Saud University - College of Education, 28(3), 455 - 473. http://search.mandumah.com/Record/866597

Al-Mutairi, A. B. Z. (2020). Perceived organizational support and its relationship to work stress among teachers of general education schools in Al-Mahd Governorate. Reading and Knowledge Magazine, 20(1), 63-94.

Al-Otaibi, A. G. (2003). Job burnout among workers in the Kuwaiti civil service sector and its relationship to personality type (a) and the desire to leave work. Journal of Social Sciences, 2(31). pp. 347-390. 
Hareem, H. (2007). Organizational Behavior: Individuals Behavior in Organizations. Amman: Zahran Publishing and Distribution House.

Kwakman, K. (2001). Work stress and work-based learning in secondary education: Testing the Karasek model. Human resource development international, 4(4), 487-501.

Lutfi, H. M. J. (2019). Work stress and its relationship to the level of organizational commitment among teachers of the second cycle of basic education schools in Menoufia Governorate. Journal of the Faculty of Education: Benha University Faculty of Education, 30(118),147 - 200.http://search.mandumah.com/Record/974783

McManus, I. C., Keeling, A., \& Paice, E. (2004). Stress, burnout and doctors' attitudes to work are determined by personality and learning style: a twelve year longitudinal study of UK medical graduates. BMC medicine, 2(1), 1-12.

Mohammed, Y. A. (2015). Psychological stress among teachers and their counseling needs. Journal of Educational Research Center, Qatar University.

Na-Nan, K., Chaiprasit, K., \& Pukkeeree, P. (2018). Factor analysis-validated comprehensive employee job performance scale. International Journal of Quality \& Reliability Management.

Singh, N., \& Srivastava, D. R. (2018). A Study on Qualification as a Factor Effecting Stress on Faculties of Private Universities in The State of Uttar Pradesh, India. Pacific Business Review International, 10(9), 145-153.

Stora, J. B. (2011). Anguish: psychological stress. Translated by Wajih Asaad. Amman: Dar Al-Bashaer 